\title{
Evaluation of surface water quality using water quality indices (WQIs) in Lake Sukhna, Chandigarh, India
}

\author{
Maansi $^{1} \cdot$ Rajinder Jindal ${ }^{2} \cdot$ Meenu Wats $^{1}$ (D)
}

Received: 13 August 2020 / Accepted: 8 November 2021 / Published online: 21 November 2021

(c) The Author(s) 2021

\begin{abstract}
To assess the surface water quality of Sukhna Lake, 13 physico-chemical parameters like temperature, $\mathrm{pH}$, transparency, dissolved oxygen, electrical conductivity, total dissolved salts, chloride, total Aalkalinity, total hardness, calcium, magnesium, nitrate and phosphate were investigated on monthly basis for a period of two year (July 2016-June 2018) by using standard procedures. The results were compared with the values or ranges mentioned by standard organizations (WHO and BIS) for assessing the water quality and these revealed that the lake water was turbid and under DO distress. Various water quality indices like water quality index (WQI), Canadian Council Ministry of Environment (CCME)-WQI and comprehensive pollution index (CPI) were used to assess the water quality status in the Sukhna Lake. The range of WQI (59.74-83.49) indicated that the water quality status of the lake belonged to good category while those of CCME-WQI (52.4-81.61) revealed that water quality fallen from marginal to good category and those of CPI (0.4-0.7) indicated fair state of water in the lake. Overall the water quality in Sukhna Lake has been found deteriorated during second year in comparison the first year during the study time.
\end{abstract}

Keywords Canadian Council Ministry of Environment-Water Quality Index (CCME-WQI) - Comprehensive pollution index (CPI) $\cdot$ Pearson's correlation matrix $\cdot$ Surface water quality $\cdot$ Sukhna Lake $\cdot$ Water quality index

\section{Introduction}

Lakes are considered as one of the most fertile, productive, diverse and interactive aquatic ecosystems in the world. These are important freshwater resources which in-house numberless threatened and endangered aquatic flora and fauna. The quality of water in these aqua-resources depends upon many factors which in turn governs the type of life these can support (Qureshimatva et al. 2015). Lakes provide about half of global renewable freshwater and play a vital role in the socio-economic development for human welfare (Johnson et al. 2001).

Surface water contaminants are generally the discharge of municipal and industrial wastes, agricultural runoffs along with weathering of rocks, soil leaching and mining processes

Meenu Wats

meenuwats@yahoo.co.in

1 Department of Zoology, DAV College, Sector-10, Chandigarh, India

2 Department of Zoology, Punjab University, Chandigarh, India
(Bhateria and Jain 2016). The decline in surface water quality not only poses a threat to its aquatic life but also impairs underground water quality thereby effecting human health too (Wats et al. 2019) Thus, it becomes imperative to have a regular check on the health status of these natural valued resources by evaluating their physico-chemical and biological parameters (Venkatesharaju et al. 2010). Variety of methods and techniques, to assess the water quality, have been proposed and adopted by workers throughout the world of which the most effective approach is the use of water quality indices (WQIs) of different types (APHA, 2005).

WQIs are considered as reliable tools to judge and match water demand and supply. The indices are very important for any aquatic environmental monitoring programme for their management. The index value of water quality is the result of conversion of multivariate and multi-parameter water analysis data to some single digit score. It is the simplest and minimised version to represent a complex data using selected variables and methods for weighing and aggregating the variables (Kachroud et al. 2019 and Tirkey et al. 2013). A number of studies have reported the use and importance of WQIs in assessing the water quality of lakes around the 
world (Kukrer and Mutlu 2019; Wang et al. 2019; Goher et al. 2017; Trikoilidou et al. 2017; Alexakis et al. 2016; Shizi et al. 2016; Kankal et al. 2012; Hurley et al. 2012).

Sukhna Lake, a man-made rain fed freshwater reservoir, is an integral part of the master plan of "City Beautiful, Chandigarh" that provides a source of recreation and sports to de-stress its residents along with acting as a favourite site for migratory birds like Siberian duck, Storks and Cranes during winter season. The Lake also has the longest rowing channel in Asia and sports like rowing, kayaking, boating, etc. are regularly organized here. The lake is primarily used by the local residents and tourists for refreshment purposes like boating, morning and evening walks and sight-seeing. The side effects of demographic expansion of the city itself and its neighbouring states along with climatic and seasonal disturbances have affected the lake's water quality to such an extent that city's administration has to undertake regular de-siltation drives (Shrumdan), manual and mechanical as well, along with artificial recharging of water in the lake.

Currently, the water body is facing serious issues like siltation, infestation of weed, degradation of catchment area, less rain falls, addition of pollutants, etc. and all these are jeopardizing this beautiful ecosystem. In order to conserve the lake, in July 2019, U.T. administration has declared it a wetland according to the conditions laid down by Government of India's Wetland (Conservation and Management) rules, 2017 under the Environment (Protection) Act. There are a very few studies on the assessment of water quality of Sukhna Lake which have helped the local administration in the management of the resource (Manzoor et al. 2017; Dadwal et al. 2014; Chaudhary et al. 2013; Tyor and Chawla, 2012). Keeping the importance and need in view, the present study was designed to understand the seasonal variation in the physico-chemical parameters of surface water in Sukhna Lake. The water quality was assessed using different water quality indices.

\section{Methodology}

\section{Study area}

Sukhna Lake $\left(32^{\circ} 42^{\prime} \mathrm{N}\right.$ and $\left.76^{\circ} 54^{\prime} \mathrm{E}\right)$ is an artificial rainfed lake, which covers an area of $3 \mathrm{~km}^{2}$ with a catchment area of $42.07 \mathrm{~km}^{2}$ built in 1958 in the foothills of Shivalik range of Himalaya in the north-east corner of the city by damming Sukhna Choe. A roughly kidney shaped lake is $4.88 \mathrm{~m}$ depth (average $2 \mathrm{~m}$ ), $1.52 \mathrm{~km}$ long and $1.49 \mathrm{~km}$ wide with water spread area of $1.5 \mathrm{~km}^{2}$. Two seasonal rivulets viz. Kansal and Saketri along with Nepali Choe also contribute their water to the lake (Siddiqui et al. 2013 and Chaudhary et al. 2013). Sukhna has been declared as one of the national wetlands with utmost conservation priority (Nagarkoti, 2020).

\section{Sample collection and analysis}

Water samples were collected on monthly basis for 2 years (July 2016-June 2018). Parameters like surface water temperature, $\mathrm{pH}$ and transparency were measured in the field with the help of digital thermometer, E-Merck's pH meter and Sacchi disc, respectively. The water samples were collected in two separate polyvinyl propylene bottles $(1 \mathrm{~L}$ and $500 \mathrm{ml}$ ) by dipping completely into the water to avoid mixing of air bubbles. The water sample in $1 \mathrm{~L}$ bottle was used for the analysis of parameters like electrical conductivity, total dissolved salts, chloride, total alkalinity, total hardness, calcium, magnesium, nitrate and phosphate, while the sample in second bottle $(500 \mathrm{ml})$ was fixed on the spot using $2 \mathrm{ml} \mathrm{MnSO}_{4}$ and was used for dissolved oxygen analysis. (Fig. 1)

Chemical parameters were analysed using different methods. Like electrical conductivity and total dissolved salts were measured using E-Merck's conductivity and TDS metre, respectively. Chloride by titration method using $0.014 \mathrm{~N}$ silver nitrate as titrant and potassium chromate as an indicator, total alkalinity by titration method using $0.02 \mathrm{~N}$ standard sulphuric acid as titrant and phenolphthalein/ methyl orange as indicators, total hardness by EDTA titrimetric method. Nitrate and phosphate were measured using Brucine method and Stannous chloride method, respectively, with the help of UV-Vis spectrophotometer.

The 12 months of a year were categorized into following four seasons:

\begin{tabular}{ll}
\hline Monsoon & July - August \\
Post Monsoon & September- October \\
Winter & November - February \\
Summer & March - June \\
\hline
\end{tabular}

\section{Water quality index (WQI)}

WQI was calculated using ten selected water parameter, mentioned in Table 1. The calculation and formulation of the WQI involved the following four steps (Alobaidy et al. 2010).

Step 1 Each parameter has been assigned a weight $\left(\mathrm{AW}_{\mathrm{i}}\right)$ ranging from 1 to 4 depending on the collective expert opinions taken from previous studies (Kangabam et al. 2017; Prerna et al. 2014 and Ramakrishnaiah et al. 2009). Assigned weight of 1 stands for the least significant parameter and 4 as the most significant (Table 1).

Step 2 The relative weight (RW) was calculated using equation: 
Fig. 1 Study area with site location

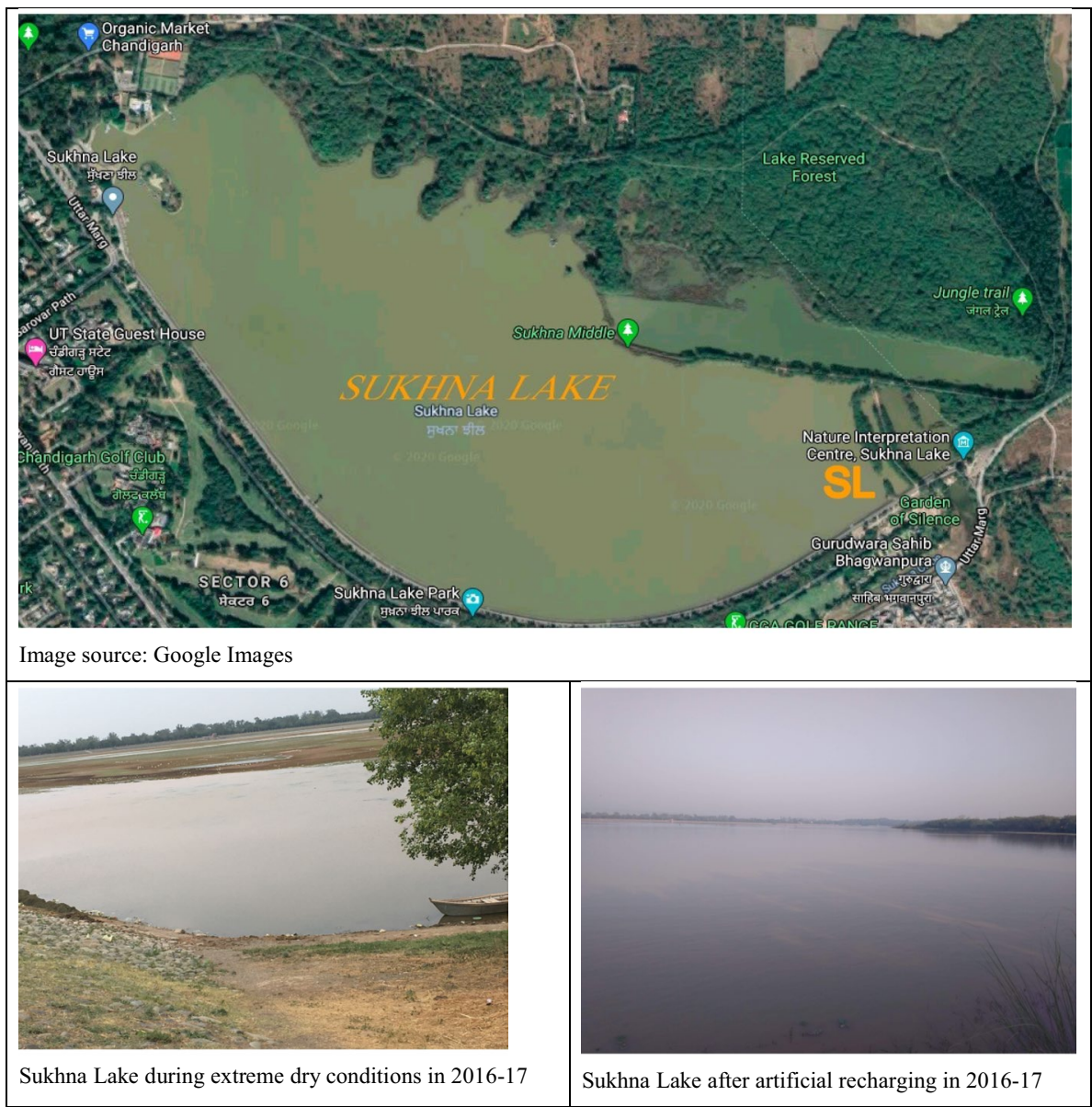

Table 1 Relative weight of each selected parameter

\begin{tabular}{llll}
\hline Parameter & Standard Value (BIS) & $\begin{array}{l}\text { Assigned } \\
\text { weight } \\
(\mathrm{AW})\end{array}$ & $\begin{array}{l}\text { Relative } \\
\text { weight } \\
(\mathrm{RW})\end{array}$ \\
\hline $\mathrm{pH}$ & $6.5-8.5(8)$ & 2.54 & 0.08631 \\
$\mathrm{EC}(\mu \mathrm{S} / \mathrm{cm})$ & 250 & 3.22 & 0.10941 \\
$\mathrm{TDS}(\mathrm{mg} / \mathrm{l})$ & 1000 & 2.75 & 0.09344 \\
$\mathrm{DO}(\mathrm{mg} / \mathrm{l})$ & 5 & 4.09 & 0.13897 \\
$\mathrm{TA}(\mathrm{mg} / \mathrm{l})$ & 200 & 3.72 & 0.1264 \\
$\mathrm{TH}(\mathrm{mg} / \mathrm{l})$ & 100 & 1.46 & 0.04961 \\
$\mathrm{Calcium}(\mathrm{mg} / \mathrm{l})$ & 75 & 2.71 & 0.09208 \\
Chloride $(\mathrm{mg} / \mathrm{l})$ & 250 & 4.02 & 0.1366 \\
Nitrate $(\mathrm{mg} / \mathrm{l})$ & 50 & 2.57 & 0.08733 \\
Magnesium $(\mathrm{mg} / \mathrm{l})$ & 30 & 2.35 & 0.07985 \\
\hline
\end{tabular}

$R W=\frac{A W_{i}}{\sum_{i=1}^{n} A W_{i}}$

where $\mathrm{RW}=$ the relative weight.

$\mathrm{AW}=$ the assigned weight of each parameter.

$\mathrm{n}=$ number of parameters.
Step $3 \times A$ quality rating scale $\left(\mathrm{Q}_{\mathrm{i}}\right)$ for all the parameters (except $\mathrm{pH}$ and $\mathrm{DO}$ ) was calculated by using equation:

$Q_{i}=\left(\frac{C_{i}}{S_{i}}\right) \times 100$

where $\mathrm{C}_{\mathrm{i}}=$ Observed value of ith parameter.

$S_{i}=$ Standard value of ith parameter.

For $\mathrm{pH}$ and $\mathrm{DO}$, the $\mathrm{Q}_{\mathrm{i}}$ was calculated by using given equation:

$Q_{i}=\left(\frac{C_{i} V_{i}}{S_{i} V_{i}}\right) \times 100$

where $\mathrm{V}_{\mathrm{i}}=$ Ideal value which is considered as 7.0 for $\mathrm{pH}$ and 14.6 for DO.

Step 4 For computing the WQI, first the sub-indices $\left(\mathrm{SI}_{\mathrm{i}}\right)$ were calculated for each parameter using following equation:

$S I_{i}=R W \times Q_{i}$

Finally, WQI was calculated using equation: 
$W Q I=\sum_{i=1}^{n} S I_{i}$

The WQI values were classified into different categories according to Ramakrishnaiah et al. 2009 (Table 2).

\section{Canadian council of ministers of the environment water quality index (CCME-WQI)-}

The CCME-WQI was used by various Indian authors to assess the surface water quality of lakes (Usman et al. 2018 and Shizi et al. 2016). The calculation of index scores in CCME-WQI method was obtained by using following equation:

$W Q I=100-\frac{\sqrt{F_{1}^{2}+F_{2}^{2}+F_{3}^{2}}}{1.732}$

where

$F_{1}($ Scope $)=$ the number of variables, whose objectives are not met

$F_{1}=\left(\frac{\text { No. of failed var iabes }}{\text { Total no.of variables }}\right) \times 100$

$\mathrm{F}_{2}($ Frequency $)=$ the number of times by which the objectives are not met

$F_{2}=\left(\frac{\text { No.of failed test }}{\text { Total no.of test }}\right) \times 100$

$\mathrm{F}_{3}($ Amplitude $)=$ Amount by which the objectives are not met.

$F_{3}=\frac{n s e}{0.01 n s e+0.01}$.

Normalized sum of excursions (nse) $=\frac{\sum_{i=1}^{n} \text { excursion }}{\text { Number of tests }}$

Excursion $=\left(\frac{\text { Faied test value }}{\text { Guideline value }}\right)-1$

The computed CCME-WQI will be classified according to CCME (2001) (Table 2).

\section{Comprehensive pollution index (CPI)}

The CPI was followed by Kamboj et al. (2017) and Matta and Kumar, (2015) to classify the water quality status. It was calculated by using following equation:

$C P I=\frac{1}{n}-\sum_{i=0}^{n} P I$

where

$\mathrm{PI}=$ pollution index of individual parameter.

$\mathrm{n}=$ number of parameters

$P I=\left(\frac{C_{i}}{S_{i}}\right)$

where $\mathrm{C}_{\mathrm{i}}=$ Observed value of $\mathrm{i}^{\text {th }}$ parameter.

$S_{i}=$ Standard value of $i^{\text {th }}$ parameter.

The CPI values were classified into different categories according to Gautam, 2017 (Table 2).

\section{Statistical analysis}

Data were analysed using SPSS vs 18.0 for calculating Pearson's correlation coefficients amongst different water parameters to study the linear relationship between them. Significance level of tests was taken as $p<0.05$ and highly significant as $\mathrm{p}<0.01$.

\section{Results and discussions}

\section{Physico-chemical analysis of water quality (Fig. 2)}

\section{Temperature}

It is one of the influential parameter which directly or indirectly affects number of other water quality determinants like pH, dissolved oxygen and alkalinity (Khaiwal et al. 2003). The surface water temperature of Sukhna Lake ranged from 15.2-33.4 ${ }^{\circ} \mathrm{C}$ throughout the study period. Maximum
Table 2 Water quality scale for different indices

\begin{tabular}{lllll}
\hline Water Quality & $\begin{array}{l}\text { WQI (Ram- } \\
\text { akrishnaiah et al. } \\
\text { 2009) }\end{array}$ & $\begin{array}{l}\text { CCME WQI } \\
\text { CCME (2005) }\end{array}$ & Water Quality & CPI (Gautam, 2017) \\
\hline Excellent & $<50$ & $95-100$ & Excellent & $<0.20$ \\
Good & $50-100$ & $80-94$ & Good & $0.21-0.40$ \\
Poor/Fair & $100-200$ & $60-79$ & Fair & $0.41-1.00$ \\
Very Poor/Marginal & $200-300$ & $45-59$ & Poor & $1.01-2.0$ \\
Unsuitable/Poor & $>300$ & $0-44$ & Very Poor & $>2.01$ \\
\hline
\end{tabular}


Fig. 2 Graphs showing average and standard deviation of different physico-chemical parameters of water quality during different seasons of both study years
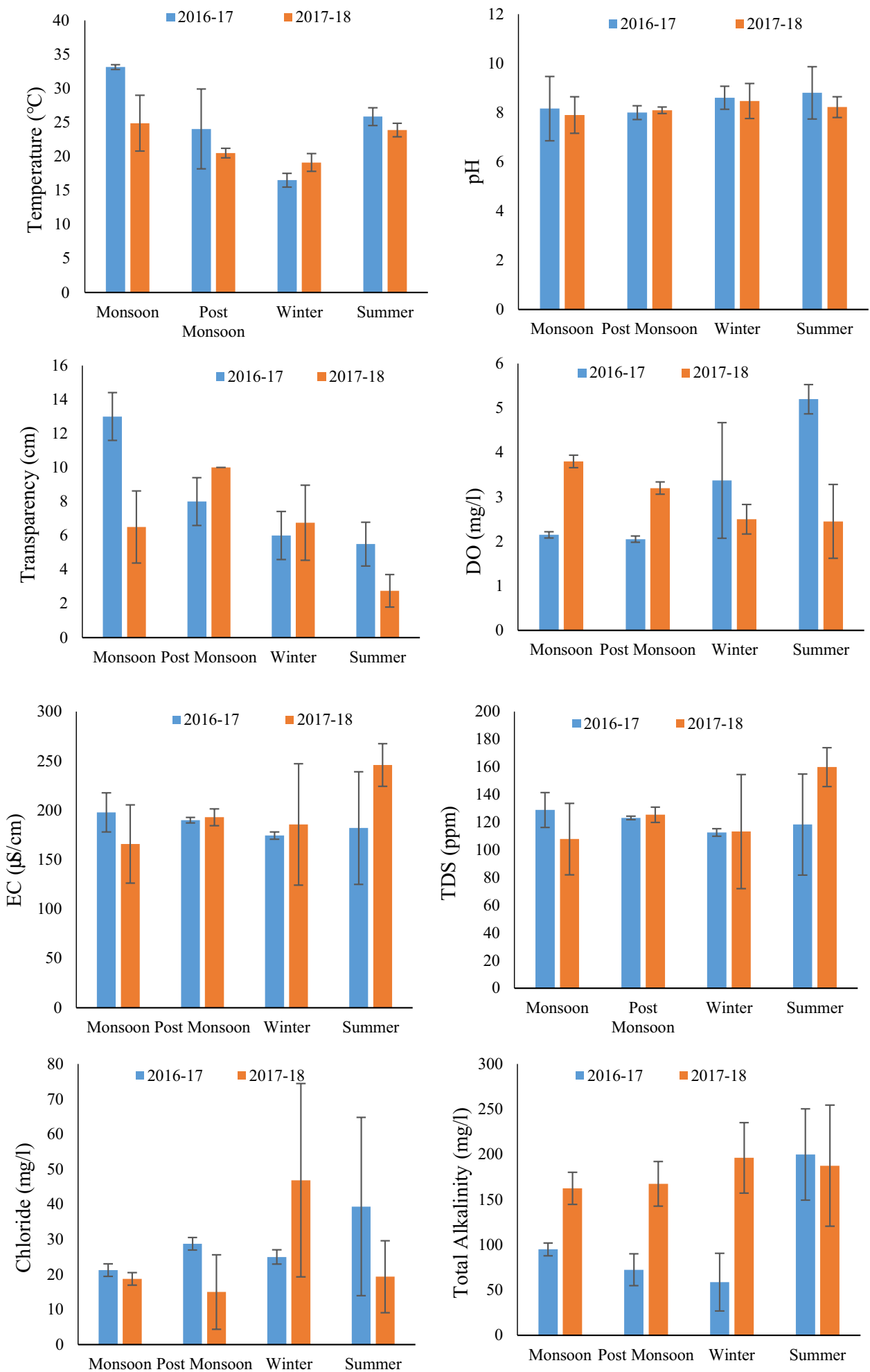

surface water temperature was recorded during monsoon while minimum in winter seasons. In 2016-17, it was found highest in monsoon $\left(32.9-33.4{ }^{\circ} \mathrm{C}\right)$ followed by summer $\left(24.6-27^{\circ} \mathrm{C}\right)$, post monsoon $\left(19.9-28.2^{\circ} \mathrm{C}\right)$ and winter season $\left(15.2-17.5^{\circ} \mathrm{C}\right)$. Similar trend was observed in $2017-18$, with highest in monsoon $\left(22-27.8^{\circ} \mathrm{C}\right)$, followed by summer (23-25.3 $\left.{ }^{\circ} \mathrm{C}\right)$, post monsoon $\left(20-21{ }^{\circ} \mathrm{C}\right)$ and winter season $\left(18-21{ }^{\circ} \mathrm{C}\right)$. Surface water temperature of Sukhna Lake in 2017-18 witnessed a slight fall in comparison with 2016-17 except in the winter season. Tyor and Chawla, (2012) in 
Fig. 2 (continued)
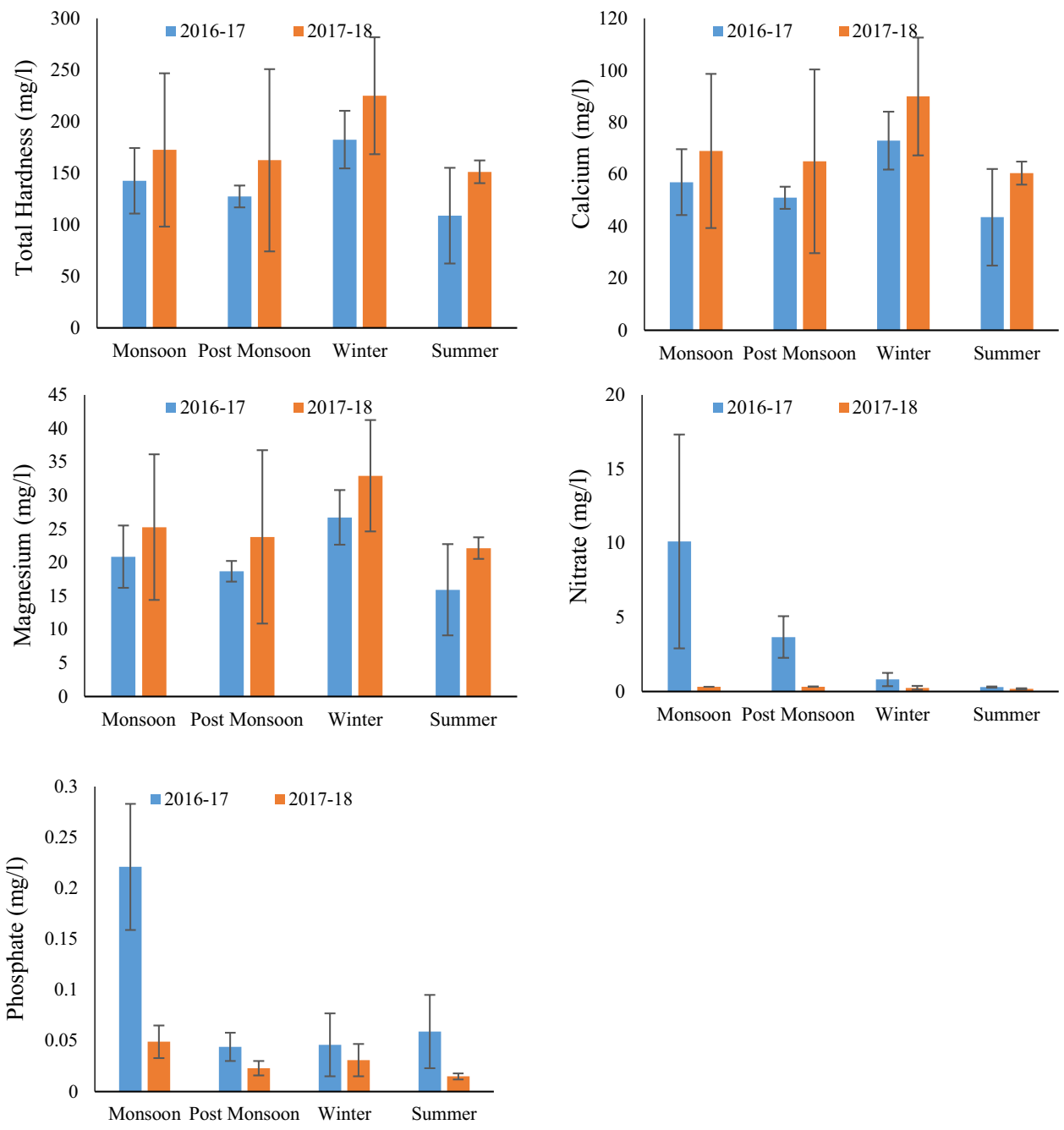

their investigation on Sukhna Lake also observed higher water temperature in monsoon season. Similar trend was also reported by Kangabam et al. (2017).

$\mathrm{pH}$

$\mathrm{pH}$ measures the acid/base activity in solution and is expressed as negative $\log$ of the concentration of $\mathrm{H}^{+}$ions. The higher $\mathrm{pH}$ value witnessed increase in productivity of lake (Ravi kumar et al. 2013; Gopalkrushna, 2011 and Garg et al. 2010). Water in Sukhna lake was found alkaline (7.2-9.9) and productive in nature. In 2016-17, maximum $\mathrm{pH}$ was recorded in summer season (7.87-9.9) followed by winter (8.1-9.2), post monsoon (7.8-8.2) and monsoon season (7.23-9). Similar observations were also recorded by Kodom et al. (2018) and Singh et al. (2020) in a tropical lake in Ghana and Fateh Sagar lake, respectively. Lowering of $\mathrm{pH}$ in monsoon season was due to dilution of lake water by rains, high rate of decomposition and low photosynthetic activity (Rawal et al. 2018 and Kodom et al.
2018). In 2017-18, water was found more alkaline in winter season (7.9-9.5) followed by summer (7.7-8.7), monsoon (7.44-8.5) and post monsoon season (8-8.1). A narrow fall in $\mathrm{pH}$ values was observed in 2017-18 in comparison with 2016-17. A neutral to slightly alkaline nature of Sukhna Lake water was also documented by Manzoor et al. (2017); Dadwal et al. (2014) and Chaudhary et al. (2013) in their respective studies.

\section{Transparency}

Transparency or penetration of light in water depends on number of factors like presence and extent of suspended organic matter, silt, plankton density, latitude, season, etc. (Reid and Wood 1976). The transparency in Sukhna Lake ranged from 1-14 cm during entire study period. Maximum transparency in 2016-17 was recorded during monsoon season $(12-14 \mathrm{~cm})$ followed by post monsoon $(7-9 \mathrm{~cm})$, winter $(5-8 \mathrm{~cm})$ and summer season $(4-7 \mathrm{~cm})$, while during 2017-18, water was found more clear in post monsoon 
season with the highest transparency $(10 \mathrm{~cm})$ followed by winter $(4-9 \mathrm{~cm})$, monsoon $(1-8 \mathrm{~cm})$ and summer season $(2-4 \mathrm{~cm})$. The high transparency in monsoon and post monsoon was due to increase in water level because of rains, which favoured submerged aquatic vegetation growth resulted in the lowering of transparency in forthcoming seasons (Istvanovics et al. 2008 and Gallegos 2001). The low transparency in summer season during both the study years was due to low water level and increased phytoplankton biomass. The same observations were observed in Poyang Lake of China (Wu et al. 2015). Transparency can also change with respect to time. For example, a large rainstorm could drastically reduce the transparency.

\section{Dissolved oxygen}

DO of a water body depends on numerous factors like temperature, photosynthetic activity, wind action, respiratory process of the life in it, pollution load, etc. It fluctuates daily, seasonally and with temperature variations as well (Wavde and Arjun 2010). In 2016-17, maximum dissolved oxygen was recorded during the summer $(5-5.7 \mathrm{mg} / \mathrm{l})$ followed by winter $(2.3-5.2 \mathrm{mg} / \mathrm{l})$, monsoon $(2.1-2.2 \mathrm{mg} / \mathrm{l})$ and post monsoon season $(2-2.1 \mathrm{mg} / \mathrm{l})$ while in $2017-18$ maximum dissolved oxygen was found in monsoon (3.7 $-3.9 \mathrm{mg} / \mathrm{l})$ followed by post monsoon $(3.1-3.3 \mathrm{mg} / \mathrm{l})$, winter $(2.1-2.9 \mathrm{mg} / \mathrm{l})$ and summer season $(2-3.7 \mathrm{mg} / \mathrm{l})$. The unusual hike of dissolved oxygen in summer season of 2016-17 was because of pumping of million gallons of water into the Lake during last month of the preceding winter (Victor 2017). The results of present investigation were favoured by Kodom et al. (2018) findings on Volta Lake, Ghana while disagreed with Kangabam et al. (2017) observation on Loktak Lake, Manipur.

\section{Electrical conductivity}

EC is the ability of water to conduct an electric current and that depends on the presence of anions and cations, their relative and total concentrations, mobility and temperature at the time of measurement (APHA 2005). The electrical conductivity of the water in Sukhna Lake ranged from $116-273 \mu \mathrm{S} / \mathrm{cm}$. Results of sampling in 2016-17 showed higher electrical conductivity in monsoon $(184-212 \mu \mathrm{S} /$ $\mathrm{cm})$ followed by post monsoon $(188-192 \mu \mathrm{S} / \mathrm{cm})$, summer $(144.9-267 \mu \mathrm{S} / \mathrm{cm})$ and winter season $(171-179 \mu \mathrm{S} /$ $\mathrm{cm}$ ) which are in concurrence with the findings of Divya and Kani, (2018) and Kangabam et al. (2017). Contrary to this in 2017-18, higher electrical conductivity value was observed in summer $(222-273 \mu \mathrm{S} / \mathrm{cm})$ followed by post monsoon $(187-199 \mu \mathrm{S} / \mathrm{cm})$, winter $(116-264 \mu \mathrm{S} / \mathrm{cm})$ and monsoon season $(137.9-194 \mu \mathrm{S} / \mathrm{cm})$ and similar findings were recorded by Verma et al. (2012). Lower values of electrical conductivity are considered as an indication of healthy water (Sharma and Kumar, 2017 and Shah et al. 2008).In the present study, the electrical conductivity of Sukhna Lake was found lesser than the values reported by Tyor and Chawla, (2012) from the same water body.

\section{Total dissolved salts}

Electrical conductivity is considered as an indirect measure of total dissolved salts (Alobaidy et al. 2010 and Harilal et al. 2004). Total dissolved salts reflect the amount of inorganic salts and small amount of organic matter dissolved in water. Similar seasonal trend was observed between total dissolved salts and electrical conductivity values. The total dissolved salts of Sukhna Lake water fluctuated between $75.4-177.4 \mathrm{mg} / \mathrm{l}$ during both study years. In 2016-17, maximum total dissolved salts were found during monsoon (120-137.8 mg/l) followed by post monsoon $(122.2-124 \mathrm{mg} / \mathrm{l})$, summer $(96.3-173 \mathrm{mg} / \mathrm{l})$ and winter season (110.1-116.3 mg/l), while in 2017-18, maximum total dissolved salts value was observed in summer $(144.2-177.4 \mathrm{mg} / \mathrm{l})$ followed by post monsoon $(121.5-129.3 \mathrm{mg} / \mathrm{l})$, winter $(75.4-171.6 \mathrm{mg} / \mathrm{l})$ and monsoon season (89.6-126.1 mg/l). Higher total dissolved salts values in summer season attributed to faster rate of evaporation and decomposition activities, while similar results in monsoon season were due to the addition of surface runoffs by heavy precipitation. Manzoor et al. (2017) reported lower total dissolved salts value $(<100 \mathrm{mg} / \mathrm{l})$ in his study on the same water body.

\section{Chloride}

The source of chloride is mainly inorganic salts like $\mathrm{NaCl}$ and $\mathrm{KCl}$ in the water that mainly comes from soil, animal wastes and municipal and industrial wastes (Gopalkrushna 2011). It is also considered as an important indicator of water pollution (Podhade et al. 2020). In Sukhna Lake, amount of chloride ranged from 7.49-87.4 mg/l. In 2016-17, higher values of chloride were recorded during summer (24.9-77.4 $\mathrm{mg} / \mathrm{l})$ followed by post monsoon (27.4-29.9 mg/l), winter (22.4-27.4 mg/l) and monsoon season (19.9-22.4 mg/l). The high chloride content in summer season was due to increase in evaporation rate. Similar observation was made by Usman et al. (2018) and Verma et al. (2012). In 2017-18, maximum concentration of chlorides was observed in winter $(27.4-87.4 \mathrm{mg} / \mathrm{l})$ followed by summer $(9.9-32.4 \mathrm{mg} / \mathrm{l})$, monsoon $(17.4-19.9 \mathrm{mg} / \mathrm{l})$ and post monsoon season $(7.4-22.49 \mathrm{mg} / \mathrm{l})$. The high chloride value in winter season could be due to poor ability of cold water to dilute any waste in lake water. Similar pattern of seasonal fluctuations was reported by Bhat and Pandit (2014) in Wular Lake of Kashmir. The higher chloride

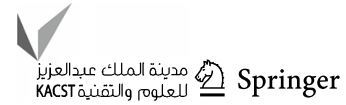


content in water could be due to the addition of pollution by anthropogenic activities and sewage disposal as proposed by (Chatterjee et al. 2010).

\section{Total alkalinity}

Total alkalinity expresses the buffering capacity of water which will help in maintaining its $\mathrm{pH}$ (Lodh et al. 2014). Alkalinity is the measure of the ability of water to neutralize acids. It is generally not considered as a pollutant (Sharma and Kumar, 2017). In 2016-17, the maximum alkalinity was observed in summer (140-260 mg/l) followed by monsoon (90-100 mg/l), post monsoon $(60-85 \mathrm{mg} / \mathrm{l})$ and winter season $(35-105 \mathrm{mg} / \mathrm{l})$. High value of alkalinity in summer was due to high rate of decomposition which releases $\mathrm{CO}_{2}$ resulting in the addition of carbonate and bicarbonate ions, hence increases alkalinity level (Verma et al. 2012). In 2017-18 findings, higher alkalinity was found during winter (175-290 mg/l) followed by summer $(125-255 \mathrm{mg} / \mathrm{l})$, post monsoon $(150-185 \mathrm{mg} / \mathrm{l})$ and monsoon season (150-175 mg/l). In contrary to this, Tyor and Chawla (2012) reported high total alkalinity in Sukhna Lake during monsoon season.

\section{Total hardness, calcium and magnesium}

The hardness of water is mainly due to the cations like calcium and magnesium present in it. In 2016-17, the higher values of hardness were recorded in winter $(145-210 \mathrm{mg} / \mathrm{l})$ followed by monsoon (120-165 mg/l), post monsoon $(120-135 \mathrm{mg} / \mathrm{l})$ and summer season (70-175 mg/l) and similar trend though with higher values was also observed in 2017-18 samples with maximum hardness in winter (175-290 mg/l) followed by monsoon (120-225 mg/l), post monsoon (100-225 mg/l) and summer season (70-175 mg/l). Usman et al. (2018) reported higher hardness in urban lakes of Mumbai during summer while low in winter season. Manzoor et al. (2017) and Tyor and Chawla (2012) reported much lower values of hardness in Sukhna Lake.

Seasonal fluctuations in calcium and magnesium were also found following the similar trend as of total hardness during both the years of study. In the 2016-17, the higher values of calcium were recorded in winter $(58-84 \mathrm{mg} / \mathrm{l})$ followed by monsoon (48-66 $\mathrm{mg} / \mathrm{l})$, post monsoon $(48-54 \mathrm{mg} / \mathrm{l})$ and summer season $(70-175 \mathrm{mg} / \mathrm{l})$, while in 2017-18, maximum levels of calcium were recorded in winter (175-290 mg/l) followed by monsoon (120-225 mg/l), post monsoon (100-225 $\mathrm{mg} / \mathrm{l})$ and summer season (70-175 mg/l).

The highest magnesium concentration in 2016-17 was recorded in winter $(21.2-30.7 \mathrm{mg} / \mathrm{l})$ followed by monsoon
(17.5-24.15 mg/l), post monsoon $(17.5-19.7 \mathrm{mg} / \mathrm{l})$ and summer season (10.2-25.6 mg/l), while in 2017-18, maximum levels of magnesium were in winter $(25.6-42.4 \mathrm{mg} / \mathrm{l})$ followed by monsoon $(17.5-32.9 \mathrm{mg} / \mathrm{l})$, post monsoon (14.6-32.9 mg/l) and summer season (20.4-24.1 mg/l). The presence of magnesium indicated the contamination of sewage inflows and minerals generated due to soil erosion/siltation (Verma et al. 2012). Bhat and Pandit 2014 also recorded higher calcium and magnesium during winter season in Wular Lake, Kashmir.

\section{Nitrate}

Inorganic nitrogen is the commonest form of nitrogen in natural waters. It is the main nutrient that accelerates the growth of hydrophytes and aquatic algae (Lodh et al. 2014). Nitrate is found in relatively very low concentration in freshwaters bodies considered as exceptionally important nutrient supplier of nitrogen for protein synthesis. In the current study, higher concentration of nitrate was observed during monsoon $(5.02-15.2 \mathrm{mg} / \mathrm{l})$ followed by post monsoon $(2.67-4.67 \mathrm{mg} / \mathrm{l})$, winter $(0.16-1.15 \mathrm{mg} / \mathrm{l})$ and summer season $(0.26-0.32 \mathrm{mg} / \mathrm{l})$ in $2016-17$ and the similar trend was followed in $2017-18$ with a range of $0.31-0.32 \mathrm{mg} / \mathrm{l}$ in monsoon, $0.32-0.33 \mathrm{mg} / \mathrm{l}$ in post monsoon, $0.16-0.43 \mathrm{mg} / \mathrm{l}$ in winter and $0.14-0.23 \mathrm{mg} / \mathrm{l}$ in summer season but in lesser amount than the previous year. Similar observations were also reported by Verma et al. (2012). Influx of N rich flood water from the catchment area brings along large amount of contaminations like sewerage that accelerate nitrate levels in the monsoon season, the same was found in the current study. Bhat and Pandit (2014) also observed low nitrate during summer season in Wular Lake, Kashmir.

\section{Phosphate}

It is one of the limiting factors for productivity of any water body (Hutchinson 1957). In lakes, there are various sources of phosphate like rock deposits, runoff from the catchment areas, etc. Phosphate enters into the lake ecosystem mainly through domestic wastewater, and agricultural runoff containing fertilizers (Gopalkrushna 2011). In general, the phosphate levels were found in very low concentration in the lake. In 2016-17, the maximum levels of phosphate were recorded in monsoon $(0.17-0.26 \mathrm{mg} / \mathrm{l})$ followed by summer $(0.02-0.1 \mathrm{mg} / \mathrm{l})$, winter $(0.02-0.09 \mathrm{mg} / \mathrm{l})$ and post monsoon season $(0.03-0.05 \mathrm{mg} / \mathrm{l})$, while in $2017-18$, the higher concentration was observed during monsoon $(0.03-0.06 \mathrm{mg} / \mathrm{l})$ followed by winter $(0.01-0.05 \mathrm{mg} / \mathrm{l})$, post monsoon 
(0.01-0.02 mg/l) and summer season (0.01-0.02 mg/l). Similar findings were made by Shukla and Vyas (1994) in Rang Sagar Lake. However, Verma et al. (2012) reported higher concentration of phosphate in summer season.

\section{Pearson's correlation amongst water quality parameters (Table 3)}

The Pearson's correlation analysis was carried out to understand the possible relationship between different water quality parameters.

This study has found some highly significant correlations between the water parameters (Table 3). The correlation matrix suggested that in 2016-17, temperature was found having positive correlation with transparency, nitrate and phosphate while negative with $\mathrm{pH}$ and total hardness. Current findings were contrary to those of Medudhula et al. 2012 and Rawal et al 2018. Transparency showed a negative correlation with dissolved oxygen and strong positive correlation with nitrate and phosphate while a negative correlation amongst these was observed by Goher et al. 2017. A strong positive correlation was found between electrical conductivity and total dissolved salts, the same was also observed by other researchers too (Kangabam et al 2017; Mallick, 2017). Electrical conductivity and total dissolved salts were positively correlated with chloride (Goher et al. 2017). Dissolved oxygen had a strong positive correlation with total alkalinity while moderate negative with total hardness and nitrate. A strong positive correlation was observed between phosphate and nitrate.

During 2017-18, transparency had a strong negative correlation with temperature and moderate negative with electrical conductivity and total dissolved salts. A moderate positive correlation was observed between phosphate and nitrate, total dissolved salts and temperature, while moderate negative correlation was found between $\mathrm{pH}$ and dissolved oxygen, nitrate and alkalinity.

\section{Pearson's correlation amongst indices and water quality parameters}

Correlations were also studied amongst different types of water quality indices and water parameters. In 2016-17, Pearson's correlation analysis showed moderate positive relationship of WQI with $\mathrm{pH}$ and total hardness. CCMEWQI was found having positively correlated with dissolved oxygen, total alkalinity and total hardness negative correlation with electrical conductivity and total dissolved salts, while CPI showed positive relationship with electrical conductivity, total dissolved salts, chloride and total hardness.

During 2017-18, WQI had a negative correlation with dissolved oxygen and positive with $\mathrm{pH}$, total alkalinity and total hardness. CCME-WQI showed negative correlation with total alkalinity and total hardness, while CPI had positive relationship with total alkalinity and total hardness (Table 3).

\section{Water quality indices}

\section{WQI}

The WQI value (Fig. 3 and Table 4) of Sukhna Lake ranges from 59.74 to 83.49 and reflects good water quality in different seasons during the entire study period. Higher value of WQI in 2017-18 indicates deterioration of lake's water quality in comparison with 2016-17. Seasonal WQI varied from one season to another. Water quality was found better in post monsoon season followed by monsoon and summer, while lower water quality was found in winter during both the study years. Zandagba et al. (2017) also reported better water quality of Nokoue Lake in rainy seasons as compared to winter and summer season, while Wang et al. (2019) reported poor water quality during rainy season in two lakes in China (Lake Wuli and Lake Taihu). These seasonal variations of WQI were potentially influenced by physico-chemical parameters of water (Jiang et al. 2018 and Wu et al. 2017).

\section{CCME-WQI}

According to CCME-WQI (52.45 - 81.61) (Fig. 3 and Table 4), the water quality of Sukhna Lake falls between marginal to good category. The winter season was found having marginal water quality during both years. Rainy seasons were again found in better condition as compared to dry ones. The values of CCME-WQI in both years indicated better status of water quality in 2016-17 as compared to 2017-18. Usman et al. (2018) also used CCME-WQI and reported marginal water quality in urban lakes of Mumbai. Shizi et al. (2016) also assessed the water quality of Kavvayi Lake of Kerala using CCME-WQI and found poor quality in the lake.

\section{CPI}

The value of CPI ranged between (0.47-0.7) reflects that the water quality of Sukhna Lake falls under fair category throughout the study period. The highest CPI value was recorded during the winter season in both the study years; 


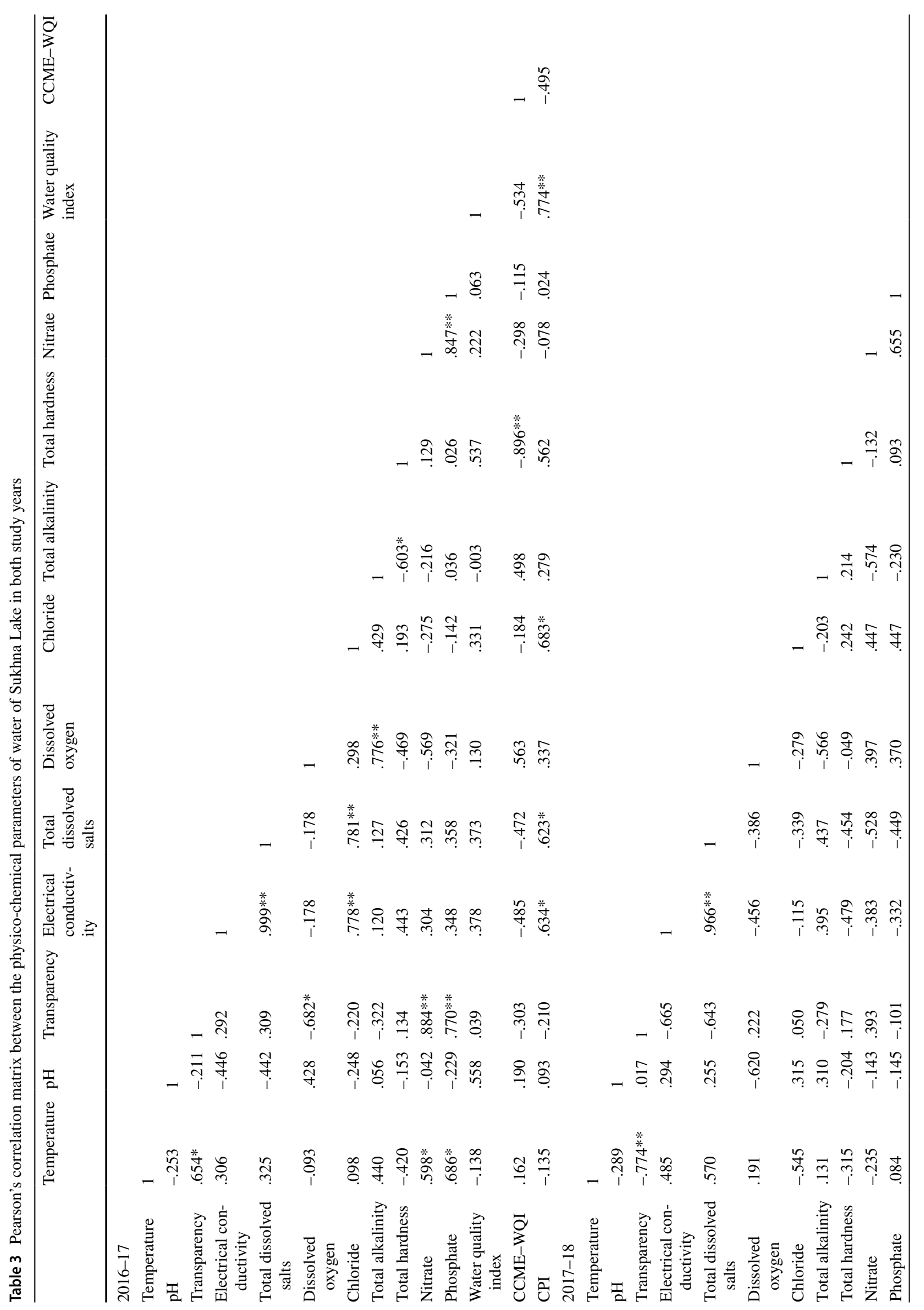




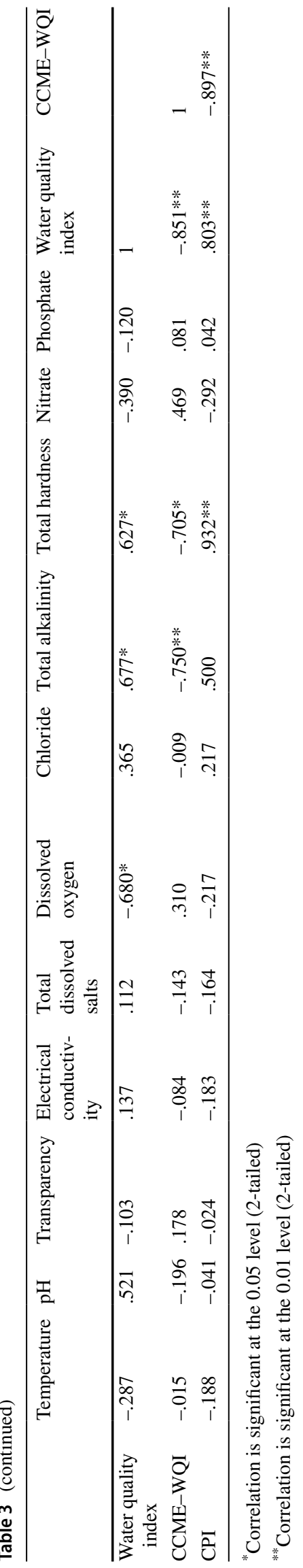

hence, the poorest water quality of all seasons and same was reported by Wu et al. (2017). The higher CPI values in 2017-18 showed better water quality existed in 2016-17 (Fig. 3 and Table 4).

\section{Conclusion}

The present study gave an overview on water quality status of Sukhna Lake which falls under National Lake Conservation Plan (NLCP). The highlights of the undertaken study are as follows:

- A of variations exists seasonally in the water quality of the lake during the span of two years.

- Though the water quality parameters were found within the permissible ranges but in much higher concentrations in comparison with earlier studies undertaken on the Sukhna Lake. Increasing hardness and alkalinity of the water in the lake were found as determining parameters altering the water quality. Dissolved oxygen was found as a determinant having positive impact on water quality. Lake was found alkaline in nature.

- The use of various water quality indices for the assessment of temporal variations in the surface water quality of Sukhna Lake were found satisfactory. The values of different WQIs revealed that the present status of the lake is not very pleasing and ranged between marginal to fair category.

- The water quality was found better during the rainy and post rainy season in comparison with dry ones (winter and summer). Water quality was found improving with more rainfall and artificial recharging of the lake in 2016-17.

- The main source of pollution in Sukhna Lake is the inflow of untreated sewage from the adjacent human habitats via various nallahs and choes along with regular siltation from its catchment areas.

- It is recommended that regular monitoring of the lake, de-weeding and desilting is the necessity of time to maintain its aesthetic value and protect the lake from any further degradation. 
Fig. 3 Plot of WQI, CCMEWQI and CPI showing seasonal variations during both study years *showing values for $2^{\text {nd }}$ year
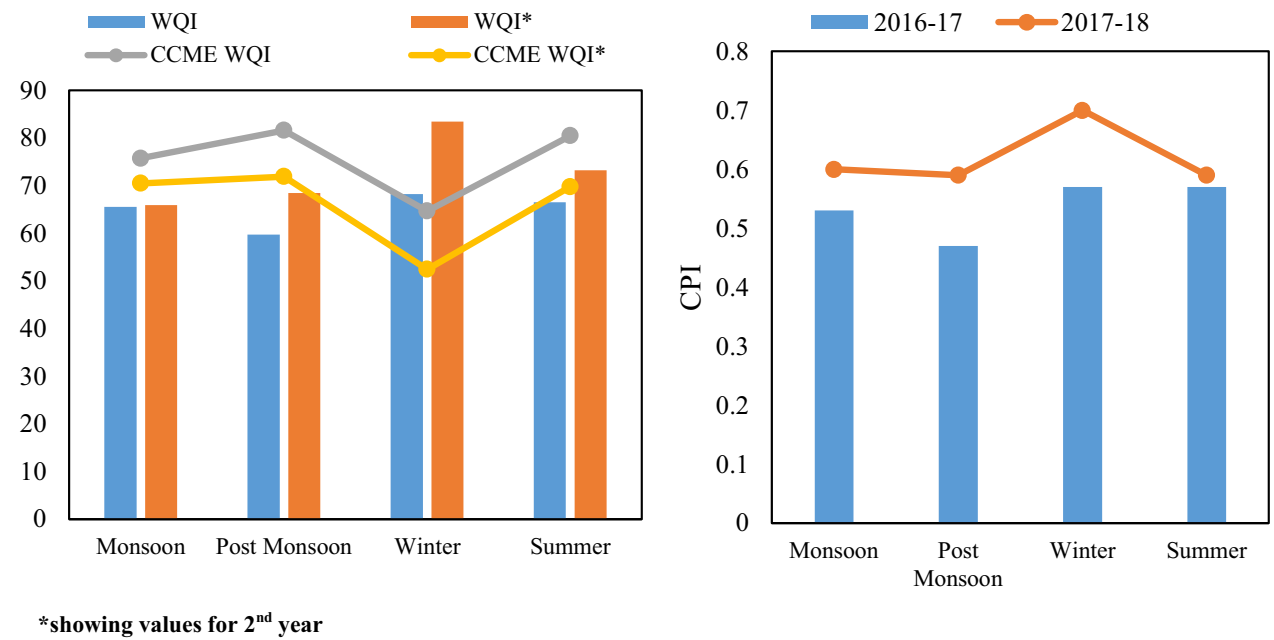

Table 4 Seasonal water quality status of Sukhna Lake according to WQI, CCME-WQI and CPI during both study years

\begin{tabular}{|c|c|c|c|c|c|c|c|c|}
\hline \multirow{2}{*}{$\begin{array}{l}\text { Site } \\
\text { Season }\end{array}$} & \multicolumn{4}{|l|}{ 2016-17 } & \multicolumn{4}{|l|}{$2017-18$} \\
\hline & Monsoon & Post Monsoon & Winter & Summer & Monsoon & Post Monsoon & Winter & Summer \\
\hline \multirow[t]{2}{*}{ WQI } & Good & Good & Good & Good & Good & Good & Good & Good \\
\hline & 65.58 & 59.74 & 68.23 & 66.51 & 65.9 & 68.49 & 83.49 & 73.27 \\
\hline \multirow[t]{2}{*}{ CCME WQI } & Fair & Good & Marginal & Good & Fair & Fair & Marginal & Fair \\
\hline & 75.76 & 81.61 & 64.67 & 80.5 & 70.48 & 71.92 & 52.45 & 69.77 \\
\hline \multirow[t]{2}{*}{ CPI } & Fair & Fair & Fair & Fair & Fair & Fair & Fair & Fair \\
\hline & 0.53 & 0.47 & 0.57 & 0.57 & 0.6 & 0.59 & 0.7 & 0.59 \\
\hline
\end{tabular}

Acknowledgements The authors would like to thank the Principal, DAV College, Chandigarh for providing laboratory and infrastructure facilities. The study was supported by a research Fellowship from Council of Scientific and Industrial Research (CSIR), India. The authors are also grateful to Ravinder Kumar for providing his assistance during sample collection and data analysis.

Funding The study was supported by a research Fellowship from Council of Scientific and Industrial Research (CSIR), India.

\section{Declarations}

Conflict of interest The authors declare that they have no conflict of interests.

Open Access This article is licensed under a Creative Commons Attribution 4.0 International License, which permits use, sharing, adaptation, distribution and reproduction in any medium or format, as long as you give appropriate credit to the original author(s) and the source, provide a link to the Creative Commons licence, and indicate if changes were made. The images or other third party material in this article are included in the article's Creative Commons licence, unless indicated otherwise in a credit line to the material. If material is not included in the article's Creative Commons licence and your intended use is not permitted by statutory regulation or exceeds the permitted use, you will need to obtain permission directly from the copyright holder. To view a copy of this licence, visit http://creativecommons.org/licenses/by/4.0/.

\section{References}

Abdul Hameedmonsoon Jawad A, Haider SA, Bahram KM (2010) Application of water quality index for assessment of Dokan lake ecosystem, Kurdistan region, Iraq. Journal of Water Resource and Protection. 2010

Alexakis D, Tsihrintzis VA, Tsakiris G, Gikas GD (2016) Suitability of water quality indices for application in lakes in the Mediterranean. Water Resour Manage 30(5):1621-1633

Alobaidy AH, Maulood BK, Kadhem AJ (2010) Evaluating raw and treated water quality of Tigris River within Baghdad by index analysis. J water Res Protect 2(7):629

Apha A (2005)WEF. Standard Methods for the Examination of Water and Wastewater 21258259

Apha A (2012) WEF. Standard methods for the examination of water and wastewater 22 .

Bhat SA, Pandit AK (2014). Surface water quality assessment of Wular Lake, a ramsar site in Kashmir Himalaya, using discriminant analysis and WQI. J. Ecosyst. 2014

Canadian Council of Ministers of the Environment (CCME) WQI (2005) Standard Methods for the examinations of water and wastewater. American Public Health Association, Washington, DC

Chatterjee R, Tarafder G, Paul S (2010) Groundwater quality assessment of Dhanbad district, Jharkhand, India. Bull Eng Geol Env 69(1):137-141

Chaudhry P, Sharma MP, Bhargava R, Kumar S, Dadhwal PJS (2013) Water quality assessment of Sukhna Lake of Chandigarh city 
of India. Hydro Nepal: Journal of Water, Energy and Environment 12:26-31

Costanza R, d'Arge R, De Groot R, Farber S, Grasso M, Hannon B, Limburg K, Naeem S, O’Neill RV, Paruelo J, Raskin RG, Sutton P, Van Den BM (1997) The value of the world's ecosystem services and natural capital. Nature 387:253-259

Dadwal J, bhatnagar B, Kumar S (2014) Assessment of physicochemical and bacteriological parameters of Sukhna Lake in Chandigarh, India. Int J Sci Res 3(9)

Divya RS, MophinKani K (2018) Water quality assessment of sasthamcotta lake, Kollam, Kerala. Int. J. Eng. Adv. Technol 7(3):119-129

Gallegos CL (2001) Calculating optical water quality targets to restore and protect submersed aquatic vegetation: overcoming problems in partitioning the diffuse attenuation coefficient for photosynthetically active radiation. Estuaries 24(3):381-397

Garg RK, Rao RJ, Uchchariya D, Shukla G, Saksena DN (2010) Seasonal variations in water quality and major threats to Ramsagar reservoir, India. African J. Environ. Sci. Technol. 4(2)

Goher ME, Hassan AM, Abdel-Moniem IA, Fahmy AH, El-sayed SM (2014) Evaluation of surface water quality and heavy metal indices of Ismailia Canal, Nile River. Egypt the Egyptian J. Aquatic Res. 40(3):225-233

Gopalkrushna HM (2011) Determination of physico-chemical parameters of surface water samples in and around Akot city. Int. J. Res. Chem. Environ. (IJRCE) 1(2):183-187

Harilal CC, Hashim A, Arun PR, Baji S (2004) Hydrogeochemistry of two rivers of Kerala with special reference to drinking water quality. Ecol. Environ. Conserv. 10:187-192

Hurley T, Sadiq R, Mazumder A (2012) Adaptation and evaluation of the Canadian Council of Ministers of the environment water quality index (CCME WQI) for use as an effective tool to characterize drinking source water quality. Water Res 46(11):3544-3552

Hutchinson GE (1957) A Treatise on Limnology. Geography, Physics and Chemistry John Wiley and Sons, Inc., New York, P 1015

Istvánovics V, Honti M, Kovács Á, Osztoics A (2008) Distribution of submerged macrophytes along environmental gradients in large, shallow Lake Balaton (Hungary). Aquat Bot 88(4):317-330

Jiang L, Li Y, Zhao X, Tillotson MR, Wang W, Zhang S, Sarpong L, Asmaa Q, Pan B (2018) Parameter uncertainty and sensitivity analysis of water quality model in Lake Taihu, China. Ecol Model 375:1-12

Johnson N, Revenga C, Echeverria J (2001) Managing water for people and nature. Science 292(5519):1071-1072

JyotiDadwal AB, Kumar S (2014). Assessment of Physicochemical and Bacteriological Parameters of Sukhna Lake in Chandigarh, India. Int. J. Sci. Res (IJSR). 3(9)

Kachroud M, Trolard F, Kefi M, Jebari S, Bourrié G (2019) Water quality indices: Challenges and application limits in the literature. Water 11(2):361

Kaiser Manzoor D, Zaman B, Rao C. Status of Sukhna Lake: a Remote Sensing and GIS Perspective. Int. J. Current Trends Sci. Technol. 7(12)

Kamboj N, Matta G, Bharti M, Kumar A, Kamboj V, Gautam RK (2017) Water quality categorization using WQI in rural areas of Haridwar, India. Essence-Int. J. Environ. Rehab. Conserv. $8(2): 108-116$

Kangabam RD, Bhoominathan SD, Kanagaraj S, Govindaraju M (2017) Development of a water quality index (WQI) for the Loktak Lake in India. Appl Water Sci 7(6):2907-2918

Kankal NC, Indurkar MM, Gudadhe SK, Wate SR (2012) Water quality index of surface water bodies of Gujarat. India Asian J Exp Sci 26(1):39-48

Kar D (2013) Wetlands and Lakes of the World. Springer, New Delhi, India, p 687
Khaiwal R, Ameena M, Rani M, Anubha K (2003) Seasonal variations in physico-chemical characteristics of River Yamuna in Haryana and its ecological best designated use. J Environ Monit 5:419-426

Kodom K, Onoyinka AA. Mkude IT, Otu SA, Yeboah JO (2018). Physicochemical parameters assessment and seasonal variations of surface water quality of the volta lake in Ghana

Kükrer S, Mutlu E (2019) Assessment of surface water quality using water quality index and multivariate statistical analyses in Saraydüzü Dam Lake. Turkey Environ. Mon. Assess 191(2):71

Lodh R, Paul R, Karmakar B, Das MK (2014) Physicochemical studies of water quality with special reference to ancient lakes of Udaipur City, Tripura, India. Int J Sci Res Publ 4(6):1-9

Mallick J (2017) Hydrogeochemical characteristics and assessment of water quality in the Al-Saad Lake Abha Saudi Arabia. Appl Water Sci 7(6):2869-2882

Manzoor K, Raj P, Sheoran R, Dey S, Gupta EJ, Zaman B, Rao C (2017) Water quality assessment through GIS: a case study of sukhna lake, Chandigarh, India. Int Res J Eng Technol 4:1773-1776

Matta G, Kumar A (2015) Monitoring and evaluation of river Ganga system in Himalayan region with reference to limnological aspects. World Appl Sci J 33(2):203-212

Nagarkoti R (2020) Within 8 months, Chandigarh reduces 72 acres of Sukhna wetland. In: The times of india

Podhade D, Lal SB, Singh S, Mehera B, Khare N, James A (2020) Evaluating the impact of wetland health on wildlife health by soil and water quality analysis. Int J Curr Microbiol App Sci 9(9):839-849

Poonam T, Tanushree B, Sukalyan C (2013) Water quality indicesimportant tools for water quality assessment: a review. Int. J. Adv. Chem. 1(1):15-28

Pradeep V, Deepika C, Urvi G, Hitesh S (2012) Water quality analysis of an organically polluted lake by investigating different physical and chemical parameters. Int J Res Chem Environ 2:105-111

Prerna S, Meher PK, Kumar A, Gautam YP, Mishra KP (2014) Changes in water quality index of Ganges river at different locations in Allahabad. Sust Water Qual Ecol 3:67-76

Qureshimatva UM, Maurya RR, Gamit SB, Solanki HA (2015) Studies on the physico-chemical parameters and correlation coefficient of sarkhej roza lake, District Ahmedabad, Gujarat. India J Environ Anal Toxicol 5(284):2161-2525

Qureshimatva UM, Maurya RR, Gamit SB, Patel RD, Solanki HA (2015) Determination of physico-chemical parameters and water quality index (Wqi) of Chandlodia Lake, Ahmedabad, Gujarat. India. J Environ Anal Toxicol 5(288):1-6

Ramakrishnaiah CR, Sadashivaiah C, Ranganna G (2009) Assessment of water quality index for the groundwater in Tumkur Taluk, Karnataka State. India J. Chem. 6(2):523-530

Ravikumar P, Mehmood MA, Somashekar RK (2013) Water quality index to determine the surface water quality of Sankey tank and Mallathahalli lake, Bangalore urban district, Karnataka. India Appl. Water Sci. 3(1):247-261

Ravindra K, Kaushik A (2003) Seasonal variations in physico-chemical characteristics of river Yamuna in Haryana and its ecological bestdesignated use. J Environ Monit 5(3):419-426

Rawal I, Joshi H, Chaudhary BL (2018) Water quality assessment using physicochemical and bacteriological parameters of Fateh Sagar Lake, Udaipur. India Water Resour. 45(3):427-435

Reid GK, Wood RD (1976) Ecology of Inland Waters and Estuaries, 2nd edn. Van Nostrand Reinhold Publishing Co., New York, p 485

Saffran K, Cash K, Hallard K, Neary B, Wright CR (2001). CCME water quality index 1.0 user's manual. Canadian water quality guidelines for the protection of aquatic life, Canadian environmental quality guidelines. Canadian Council of Ministers of the Environment.

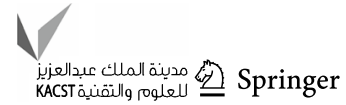


Shah MC, Shilpkar PG, Acharya PB (2008) Ground water quality of Gandhinagar Taluka, Gujarat. India J. Chem. 5(3):435-446

Sharma RC, Kumar R (2017) Water quality assessment of sacred glacial Lake Satopanth of Garhwal Himalaya. India Appl. Water Sci. 7(8):4757-4764

Sharma P, Meher PK, Kumar A, Gautam YP, Mishra KP (2014) Changes in water quality index of Ganges river at different locations in Allahabad. Sustain. Water Qual. Ecol 3:67-76

Shiji M, Sabitha AR, Prabhakar K, Harikumar PS (2016) Water quality assessment of Kavvayi Lake of Northern Kerala, India using CCME water quality index and biological water quality criteria. J Environ Biol 37(6): 1265

Shukla KB, Vyas LN (1994) Status of water quality of fresh water Lake Rang Sagar at Udaipur. Acta Ecol 160(2):129-132

Siddiqui R, Mahmood G (2013) Analysis of sustainability of Sukhna Lake and determination of hydrodynamics of Watershed of Sukhna Lake with special reference to urbanization impact assessment. Int. J. Innov. Res. Develop. 2(3):456-480

Singh RP, Mangottiri V, Pandiyan B (2020) Understanding the variability in estimation of water quality of lakes and reservoirs. In IOP Conference Series: Materials Science and Engineering. 955(1):012085

Thirupathaiah M, Samatha CH, Sammaiah C (2012) Analysis of water quality using physico-chemical parameters in lower manair reservoir of Karimnagar district, Andhra Pradesh. Int J Environ Sci 3(1):172-180

Trikoilidou E, Samiotis G, Tsikritzis L, Kevrekidis T, Amanatidou E (2017) Evaluation of water quality indices adequacy in characterizing the physico-chemical water quality of lakes. Environmental Processes 4(1):35-46

Tyor AK, Chawla D (2012). Survey and study of phytoplankton ecology in Sukhna Lake, Chandigarh, (India)

Usman A, Dube K, Shukla SP, Salaskar P, Prakash C, Sawant PB, Singh R (2018) Water quality index as a tool for assessment of status of an urban lake of Mumbai. Int J Curr Microbiol App Sci 7(04):520-533

Venkatesharaju K, Ravikumar P, Somashekar RK, Prakash KL (2010) Physico-chemical and bacteriological investigation on the river
Cauvery of Kollegal stretch in Karnataka. Kathmandu Univ. J. Sci. Eng. Technol. 6(1):50-59

Verma P, Chandawat D, Gupta U, Solanki H (2012) Water quality analysis of an organically polluted lake by investigating different physical and chemical parameters. Int J Res Chem Environ 2(1):105-111

Victor H (2017). Hindustan Times (February, 13), 7 tube wells pumping water, but Sukhna's level is same as January 16. https://www. hindustantimes.com/punjab/7-tube-wells-pumping-water-butsukhna-s-level-is-same-as-january-16/story-kcTIZmXEohrsRJo H2ZJwsM.html

Wang J, Fu Z, Qiao H, Liu F (2019) Assessment of eutrophication and water quality in the estuarine area of Lake Wuli, Lake Taihu, China. Sci Total Environ 650:1392-1402

Wats RK, Grover AS, Kumar R, Wats M (2019) Status of surface water quality in river Markanda and its correlation with ground water quality and health of the residents of Shahabad, Kurukshetra, Haryana, India-a case study. Int. J. Health Econom. Develop. 5(1):1-11

Wavde PN, Arjun B (2010) Groundwater quality assessment at Malegaon region of nanded in Maharashtra (India). J Environ Sci Eng 52(1):57-60

WHO (2004) Guidelines for drinking-water quality, World Health Organization, 3rd edn, 1. Recommendations. Geneva, Switzerland, $\mathrm{p} 515$

Wu Z, Zhang Y, Zhou Y, Liu M, Shi K, Yu Z (2015) Seasonalspatial distribution and long-term variation of transparency in Xin'anjiang Reservoir: implications for reservoir management. Int J Environ Res Public Health 12(8):9492-9507

Wu Z, Zhang D, Cai Y, Wang X, Zhang L, Chen Y (2017) Water quality assessment based on the water quality index method in Lake Poyang: the largest freshwater lake in China. Sci Rep 7(1):1-10

Zandagba JEB, Adandedji FM, Lokonon BE, Chabi A, Dan O, Mama D (2017) Application use of Water Quality Index (WQI) and multivariate analysis for Nokoué lake water quality assessment. American J. Environm. Sci. Eng. 1(4):117-127

Publisher's Note Springer Nature remains neutral with regard to jurisdictional claims in published maps and institutional affiliations. 